DIE HEDENDAAGSE WéRELDBEeLD MET TOESPITSING OP AFRIKA

\title{
G.C. Oosthuizen
}

Professor in Godsdienswetenskap, Universiteit van Durban-Westville, en hoof van Navorsingseenheid oor onafhanklike Swart kerke aan die Universiteit van Zululand

\section{ABSTRACT}

The author takes issue immediately with the fact that contemporary world views are contrasted, as a matter of course, with Africa. He discusses in detail the development of the contact between Africa and the West, pointing out to what extent and in what ways Western ways of thought have infiltrated into the African psyche. Subsequently he deals with the modern and the post-modern view of the world, pointing out that the post-modern, with its radically new ways of thought (eg. quantum physics) have implications for Africa as well. After a discussion of the views of the primal nations of Africa, and an evaluation of the sophistication of the cultures in contrast to the stereotyped view of their "primitiveness", he goes on to a discussion of their views of the divine, concluding with the idea that God is not voluntarily Deus Absconditus God is formally distant, but existentially present.

The next part of the article deals with the strong sense of community of the Black man, expressed for example in his traditional architecture. Time in the context of Africa is also discussed, with stress on the idea that the gravity point of time, for the Black man, is to be found in the past - also that the Black man controls his time, time does not control him. The advent of Western concepts created chaos in the existence of the Black man.

The article goes on to a discussion of the change that is necessary in Africa, once certain problems, due for example to the fact that Africa has not really shared in the axiological era, have been eliminated. The author comes to the conclusion that the contribution of Africa lies rather in the fact that modern man can be deflected away from being 
purely a machine through the African concept of humanity and human values.

The church in Africa is subsequently discussed, with the concluding section on changes in Africa from being a closed, sacral community to an open, plural, secular community.

Dle "PRENTJIE" VAN AFRIKa

Wanneer daar van die hedendaagse wêreldbeeld gepraat word en dit sonder meer met diẻ van Afrika gekontrasteer word, wek dit reeds vrae op. Die vernaamste vraag is of die wêreldbeelde wel nog in die laat twintigste eeu gekontrasteer kan word. Na vyf eeue van Westerse invloede via die sending op swart Afrika - baie vroeër egter onder die Berbers van Augustinus se tyd en selfs nog vroeër onder die Ethiopiërs - het daar in swart Afrika sekere veranderings plaasgevind, al was dit in baie opsigte oppervlakkig.

$\mathrm{Na}$ die ooreenkoms tussen die koloniale moondhede in Berlyn sowat ' $n$ eeu gelede oor die verdeling van Afrika het die Westerse invloede in Afrika toegeneem eintlik in die stedelike gebiede, alhoewel drie dekades gelede in sommige lande in Afrika skaars drie persent van hulle bevolkings verstedelik was. Die verwesteringsproses het toegeneem, maar omdat 'n kultuur en beskawing duisende aspekte het en die kontakgroepe hulle keuses vanuit hulle kulture maak, kan die werklike invloede van dié aspekte wat wel saak maak, flou wees. Eintlik het Afrika 'n konsumpsieverhouding eerder as 'n kreatiewe teenoor die aanbiedinge uit die natuurwetenskaplike en tegnologiese bronne van die ontwikkelde wêreld. Afrika se bevolking, wat nader kruip na die vyf honderd miljoen, en die Christendom na die twee honderd miljoen, se vlakke van verstedeliking is laag, maar die tempo warmee dit geskied in verhouding tot die totale bevolking wat in stede en dorpe woon, is van die hoogste ter wèreld (vgl. Anthony O'Connor, Johannesburg, The African City, Hutchison University Library for Africa, 1983 : p. 15). Latyns-Amerika het eers die leiding geneem, maar noudat duidelik die meerderheid daar stadsbewoners is, het Afrika die leiding begin neem sover dit die tempo van verstedeliking betref. Verstedeliking is in Afrika tans groter as in die meeste dele van Asië - Indië en Sjina ingeslote. Daar is geen $-326-$ 
verandering so dramaties of belangrik as die groei van stede nie. Die stede is die sentra van ten eerste beleid, ten tweede ekonomie - na onafhanklikheid het derduisende na die liggies van die stede geswerm met hoë verwagtinge van dit wat daar verkry kan word - en ten derde algemene ontwikkeling. Die stede word gesien as die sentra van "modernisasie", vir andere as afbrekend, van hulle tradisie, as uitbuitend van en parasities op die landelike bevolking. Verstedeliking het eerder te doen met 'n verstandelike rekonstruksie as wat dit 'n materiële fenomeen is. Byna die helfte van die bevolking van swart stede is kinders onder 15 jaar. In Afrika is die beeld wat die stede skep, een van armoede. Eintlik is die "prentjie" van Afrika tans een van agteruitgang veral na die onafhanklikheidsfase. Net $5 \%$ is welvarend, en die 10-15\% wat die middelinkomstegroep uitmaak, is spesifiek arm in vergelyking met Europese standaarde. Ook etniese verskille kenmerk die stede, met skerper verskille tussen die groepe (stamme) as in sekere ander dele van die wèreld. Die etniese verskille sny dwarsdeur klasonderskeidinge. In Suid-Afrika word dit gedemp weens die stryd teen die Blankeoorheersing. Ook is daar in Afrika sterk stedelik-landelike verhoudinge.

Die meeste Afrikalande se politieke onafhanklikheid is ontrent 25 jaar. Hulle is besig met 'n kritieke proses van nasiebou, waarin stede 'n belangrike rol speel. Daar is die koloniale stedelike tradisie en die ander waar die koloniale tradisie in gevestigde stedelike tradisies ingedring het. Daar is die verskillende tipes stede soos

(i) die inheemse stad - inheemse stedelike tradisie (Yoruba, Addis Ababa);

(ii) Moeslimstad (Zanzibar, Mogadishu);

(iii) die Koloniale stad met sy kontras tussen die funksionele en residensiële sones (Dakar, Lubumbashi);

(iv) die Europese stad - 'n spesiale koloniale stad (Harare, Bulawayo, Nairobi): 
(v) die tweeledige stad - waar elemente van twee of meer van bogenoende gekombineer word (Khartoum en Omdurman aan die Wesbank van die Nyl en Khartoum aan die teenoorgestelde kant);

(vi) heeltemal gemengde stede: 'n groot deel van dié wat na die stede emigreer, keer naderhand weer terug na die tuislande - anders as by ander stedelike bevolkings. Kulturele heterogeniteit seëvier; die taal verhinder integrasie. Etniese identiteit word egter by 'n mindere persentasie weggeskaaf. Om stedelik en landelik in Afrika sonder meer te kontrasteer is foutief. Daar is nog 'n sekere ritme tussen diè twee leefwyses.

Daar is in Afrika verskeie wêreldbeelde, naamlik diè van die Christendom, die klassieke religieuse Afrikawêreldbeeld en die verbasterde wèreldbeeld beïnloed deur die sekularisasieprosesse en sekularisme maar waar daar nog steeds 'n teruggryping na die tradisionele Afrikawéreldbeeld is.

Streng gesproke is die konstruksie van "wèreldbeelde" die werk van die filosofie; dit lè nie in die vermoē van die natuurwetenskap of die tegnologie om dit te doen nie. Ons kan dus nie van 'n natuurwetenskaplik tegnologiese wéreldbeeld praat nie ten spyte van die feit dat dit baie bygedra het tot die materiaal waaruit so 'n wéreldbeeld gebou is. Nietemin, weens die invloed vall die natuurwetenskap en die tegnologie op die moderne en die na-moderne wèreldbeeld en weens die invloed hiervan in Afrika en die veranderinge wat dit bewerkstellig, moet eers hieraan aandag gegee word voordat diè van Afrika onder bespreking kom.

DIF: MODERNE: EN NA-MODFRNE WëRELLDBEELID

Die moderne wèreldbeeld, wat tot sekularisme en filosofiese skeptisisme gelei het, is sirkelgebonde - die wêreld is 'n geslote, essensieel volledige en onveranderde, basies substantiewe en fundamenteel 'n nie-misterieuse entiteit - 'n strak geprogrammeerde masjien. Hierdie "selfaangedrewe" entiteit het die metafisika sterk in twyfel getrek en dus ook enige religieuse disposisie.

Hierteenoor is die na-moderne wèreldbeeld at meer ongebonde, onvolledig en veranderend, steeds wordende, basies rasioneel en kompleks, met $-328-$ 
groot diepte, onbeperk in sy kwalitatiewe variëteite en werklik misterieus - 'n rustelose, lewende en groeiende organisme altyd swanger aan moontlikhede vir nuwe ontwikkelinge in die toekoms (vgl. H.K. Schilling, The new consciousness in science and religion, London, SCM, 1973, p.44). Aksie, gebeurtenis en verandering word meer benadruk as substansie en gevestigdheid. Daar is gedurig 'n dialektiese spanning tussen vooruitgang en terugkering, eenvoudigheid en kompleksiteit en so meer.

Gedurende die laaste dekade van die 19de eeu was daar 'n wyd verspreide gevoel onder die meeste fisici dat al die belangrike probleme wat deur die natuur opgedis is, opgelos is en dat al die fundamentele beginsels van die fisiese wèreld bekend is. Hierdie gees word weerspieël in die katalogus van die Universiteit van Chicago 1898-99, naamlik "while it is never safe to affirm that the future of Physical Science has no marvels in store even more astonishing than those of the past, it seems probable that most of the grand underlying principles have been firmly established and that further advances are to be sought chiefly in the vigorous application of these principles to all the phenomena which come under our notice". In hierdie wêreldbeeld is die natuur streng deterministies geïnterpreteer, sodat daar geen radikaal nuwe ontwikkelinge of verrassings kan wees nie. Die wèreld self was 'n geslote entiteit, en hoe geslote was dit nie?!

Verskillende epogmakende ontdekkings soos radioaktiwiteit, Röntgenstrale, die Kwantumfenomeen - om 'n paar te noem - het skielik die mens beetgepak, en hierdie ontdekkings kon nie in die netjiese konsepsuele skemas inpas nie. Dit het die totstandkoming van radikale nuwe voorstellings geēis. So het dan die post-moderne natuurwetenskap begin, en dit handel oor die ensiklopedie van die hele natuurwetenskap en nie net oor die Fisika nie. Tans is dit nie net 'n nuwe fisika nie maar 'n nuwe psigologie, nuwe sosiologie en so meer - ook 'n nuwe tegnologie. Dit impliseer dat 'n nuwe era aangebreek het.

Hierdie "nuwe" het met nuwe wyses van denke te doen; nie net met die begripsinhoud van die natuurwetenskap nie maar ook met die manier van konseptualisering en met die basiese veronderstellings onderliggend aan sy eksperimentele en teoretiese aktiwiteite. Gedurende die tyd is die 
fundamenteelste veronderstellings van die sogenaamde eksakte wetenskappe ter syde gestel. Die 19de-eeuse fisika het ' $n$ ontoereikende begrip gehad van die diepte van die heelal en die opvattings het die rasionalistiese skepsis oor die metafisiese werklikhede aangeblaas, wat nie alleen die sekularisasieproses sonder God wou laat nie maar die mensbegrip ook aangetas het. Vandag is daar die besef dat die fisiese wèreld nie alleen nie verklaar is nie maar dat inaterie self in 'n sekere sin misterieus is; dat materie eienskappe het wat voorheen heeltemal onbekend was. Die ontdekking hiervan het op die wêreld nuwe magte losgelaat wat nooit meer beperk kan word nie. Daar het magtige nuwe wyses van denke na vore getree, sodat intuisie en gevoel met betrekking tot die ondersoek van die realiteit nie uitgesluit word nie. Dit het die merislike ondervinding geweldig uitgebrei en verryk. Groot gebiede van die werklikheid word nou ontsluit waarvan die mens nog kort gelede onbewus was.

Die gebrek aan insig betreffende die dieptedimensie van die werklikheid het gelei tot dié byna algehele onbewustheid van die misterie-aspek van die natuur wat die moderne periode oorheers het en wat sekularisme onverskillig gemaak het teenoor die religieuse aspek in die menslike bestaan. Nadat die mens bewuster geword het van die dieptedimensie in materie-energie, in ruimte-tyd, in die prosesse van die lewe, ondervind hulle meer die wonder in hulle aanraking met die natuur en dus die oorweldigende sin vir die misterie (vgl. Max Born, The restless universe, 2de druk, NY, Dover, 1951). Diepte is die sleutel wat die deur oopmaak vir die bewustheid van die diep metafisiese, waar nie net die wonder erken word nie maar ook aanbidding plaasvind. Dit dryf heen na die ryk van die religie. Dit is interessant hoedat daar weer vanaf die positiviste en linguistiese analiste soos Ayer en Ryle en andere na metafisika teruggekeer word. Daar is ' $n$ reaksie teen die harde intellektuele benadering met sy koue nadruk op objektiwiteit, terwyl die "sagter" benadering inslag vind, d.w.s. die subjektiewe, nie-rasionele, kreatiewe en idealistiese. Die oudmodiese benadering van die moderne natuurwetenskap dat die verkryging van vertroubare kennis alleenlik langs 'n streng "rasionele" weg kan geskied en dat alles daarbuite illusie is, doen nie alleen die fisiese werklikheid onreg aan nie mar ook die dieptedimensie waarin religie sy oorsprong vind. 
Bogenoemde ontwikkelings staan nie los van Afrika nie. Dit is uiters jammer dat die moderne oppervlakkige wèreldbeeld Afrika getref het en nie dié wêreldbeeld wat tans begin nie - al is dit by ' $n$ klein groepie met sy dieptedimensie. Die geweldige uitbreiding van die mens se bewustheid is grootliks an die nuwe tegnologie toe te skryf. Die wisselwerking tussen tegnologie en bewustheid werk na twee kante - die een beïnvloed die ander.

In Afrika het die elementère tegnologie ' $n$ invloed sover dit die funksionele aspek betref, maar dit word nie in Afrika vervaardig nie. Tegnologie word in ' $n$ groot mate deur die ekonomie van oorvloed beinvloed ( $v g l$. Lewis Mumford, The myth of the machine: The pentagon of power, New York, HB Jovanovich, 1970: p.395 e.v.). Die mentaliteit van die tegnologie is behep met die mite dat die masjien lei tot alles wat goed is, en dat dit die natuurbronne en energie sonder meer kan opeis. Die mite is gevoed deur die ouer wèreldbeeld, wat die wêreld as 'n masjien gesien het en die mense daartoe gelei het om ' $n$ premie te plaas op kwantitatiewe en tegniese waardes ten koste van die menslike en die betekenisvoller oorwegings van kwaliteit. Om te verhoed dat die megategnika alles oorheers, sal ' $n$ ander inodel na vore moet tree wat nie regstreeks van die masjien afgelei is nie maar van die lewende organisme en organiese kompleksiteite. Afrika, wat die mens so sterk in die sentrum plaas, kan moontlik die megategnika met biotegnika vervang.

Die postmoderne wetenskap het voorts geweldige deurbrake gemaak, en die nuwe gevoel teenoor materie het 'n nuwe kyk op die heelal gegee. Natuurwetenskaplikes praat dikwels van die ondersoek van lewe "in diepte", dit is op die molekulère vlak soos in die nuwe genetika, virologie, fisiologle en so meer. Die na-moderne wetenskap kom na vore met onverwagte soorte eienskappe wat in 'n vertikale rigting gevind word, bv. die kwantumaspekte van lig en materie. As hier van misterie gepraat word, word ook bedoel die eindelose vrae warmee elke antwoord die menslike verstand konfronteer. Elke stukkie werklikheid is onuitputlik en wys heen na misterie wat die oneindige reeks van natuurwetenskaplike vrae en antwoorde te bowe gaan. Dit veronderstel dat die mens so goed hy kan met natuurwetenskaplike onsekerhede moet leef. Die natuurwetenskap het radikaal verander en dit op so ' $n$ wyse dat die begrip misterie nie meer so vergesog klink nie. Die natuurwetenskap 
het intens menslik en persoonlik geword, en met verbeelding, intuïsie en kreatiwiteit bring dit nuwe vergesigte by die mens. Verbeelding en intuisie speel in prominenter rol.

\section{DIE TRADISIONEIE, WéRLLDBEELU VAN AFRIKA}

Hierdie wèreldbeeld kon nie by die moderne wèreldbeeld inpas nie. Daar is meer moontlikhede vir sover dit die postmoderne wèreldbeeld betref, waar daar wel weens die klem op die misterieuse aard van die heelal vir die religieuse plek is. Afrika se klassieke benadering openbaar 'n essensiële wyse van aanvoeling aangaande die fisiese en metafisiese wèreld. Vandag wil die Swartman van Afrika die siel van die kontinent self interpreteer. Dit sal tot voordeel wees van hulle wat luister na die primale interpretasie van die lewe, die mens se bestaan in die konteks van die magte van die natuur en die metafisiese wêreld.

Die primale volkere ("primitief" is taboe, soos diegene besef wat vandag met die Swart intelligentsia te doen het) is beskryf as skriftuurloos, voorgeletterd, eenvoudig in kultuur, na aan die natuur. Dit stel nie tevrede nie, want hoogs gekultiveerde volkere het ongeletterdes, en onder hulle is ook diegene wat kultureel eenvoudig is, en so meer. Die mens wat na aan die natuur lewe, is nie altyd eenvoudig wat sy kultuur betref nie. Die sogenaaknde Boesman (San), byvoorbeeld, se taal - so sê H. Sapir, die groot linguis - is net so hoog ontwikkeld as die Franse taal, wat hy as die hoogste ontwikkelde taal in die Weste beskou. Vir elke soort mier, struik, gras, boom het die Boesman 'n term; selfs woorde vir verskillende tipes reën. $H y$ is ten volle aangepas by sy omgewing. Baie van sy skilderye in die grotte, in die verre vergetelheid geskilder, vertoon vars en duidelik in die grotte - die verf van ' $n$ hoë kwaliteit en kunswerk van die kwaliteit. Dus, die woord primitief kan nie so ligtelik gebruik word nie.

Die primale volkere se mentaliteit is as 'primitief' beskrywe en dui ' $\mathrm{n}$ spesifieke tipe van denke aan wat mense soos $S$. Freud, C.G. Jung (Sielkunde), R.R. Marret (Antropologie), R. Otto en N. Söderblom (Teologie) met die sogenaamde "moderne mentaliteit" vergelyk. Lucien Levy-Bruhl (1857-1939) het van die standpunt uitgegaan, ten eerste, dat die denkprosesse van "primitiewe" volkere kontreter in uitdrukking is -332- 
en minder logies en abstrak in vorm as die rasionele benadering van die moderne mens. Hy noem dit "mistiese denke" en praat van hulle "pre-logiese" mentaliteit. Ook is hier nie kontraste nie, byvoorbeeld tussen die organiese en anorganiese, liggaam en siel, siel en materie, mens en dier nie - in alle opsigte 'n natuurmens. Ten tweede is in hierdie tipe van denke die wet van deelneming prominent, byvoorbeeld alles kan deel he aan elke ander ding, en elke wese kan die plek van 'n ander neem. Ten derde: tradisionele denke is kollektief, d.w.s. die groep kom voor die individu. Geen individu kan individualisties wees in die moderne sin van die woord nie, aangesien hy net as lid van 'n groep kan bestaan. Ook kan die groep nie op sigself bestaan nie maar bestaan in verhouding tot die bonatuurlike wèreld.

Levy-Bruhl se opvatting oor die "pre-logiese" mentaliteit van die "primitiewe" mens het tereg sterk teenstand ontvang. Die tradisioncle mens se logika kan versteur word, byvoorbeeld deur bonatuurlike ingryping of deur magiese handelinge, bygeloof en so meer. Verder is die tradisionele mens van Afirika in staat om abstrak te dink. Die tradisionele denke objektiveer die wêreld egter nie deur begrippe nie maar met beelde. Hier is die verhouding lussen denke en religie baie positiewer as in die geval van die moderne mens.

Dit word al meer besef dat die moderne benadering groot leemtes inhou. In die postmoderne periode is daar "n soort bewustheidstransformasie, omdat die oppervlakkige benadering van die 17 de tot die begin van die 20ste eeu plek maak vir 'n dieper afdaling in die geheimenisse van die planeet van ons en die heelal. Die postmoderne wetenskap het 'n merkbare invloed op die menslike - dis die wetenskap van relatiwiteit, van kwantumfisika, van die nuwe astronomie, van die nuwe biologie, met sy chromosome, gene, DNA, genetiese kodes, dieptesielkunde en so meer. Dit alles en nog meer is nie net byroegings by wat hy weet nie, maar het te doen met veranderinge in die manier waarop die mens weet - nie alleen word sy verstandelike toerusting en potensialiteite verander en verder uitgebou nie, maar die ontvanklikhede wat verlore was of geatrofeer het, word herstel of hernieu en nuwes kom na vore. Die moderne mens het in die moderne era die prooi geword van inhiberende houdings en begrippe. Intuïsie het wetenskaplike aansien gekry, en die 
belangrikheid van die nie-rasionele en transrasionele het weer in die mens se ondervinding plek begin kry.

Afrika het 'n sensitiwiteit op die nie-rasionele vlak wat wel 'n bydrae tot die hedendaagse mens se soeke na diepte kan lewer.

In Afrika is alles in wese religieus. Religie het met bestaan of syn of wese te doen en nie met ' $n$ formalistiese stellingname nie. In Swart Afrika het die Christendom hand oor hand toegeneem, en die getalleswaartekrag van die Christendom verskuif na hierdie kontinent. In die klassieke Afrika het die religie alles omvat en is dit op die wese van dinge gerig. Die volgende kategorieë behels wat bestaan: a) God (Wes-Afrika is politeïsties); b) geeste; c) mens; d) diere en plante; e) onbeliggaamde fenomene en objekte. Die mens is die sentrum van die weireld met God as die Onderhouer, en die mens het 'n mistieke verhouding met die bonatuurlike wèreld en sy omgewing. 'n Ontologiese balans moet behou word deur rituele handelinge tussen God en die mens, die voorvadergeeste (en ander geeste) en die mens en teenoor die lewendes. Hier is geen sprake van die homogenisasie van die menslike bestaan nie, dit wil sè dat hy net op een vlak lewe, soos Herbert Marcuse dit wil. Verder is agter alles 'n broeiende, ' $n$ mistieke krag wat in mense en objekte (in verskillende grade van sterkte en effektiwiteit) gevind word. Religie en magie is inmekaar gestrengel, en laasgenoemde het ook 'n belangrike rol te vervul.

Hierdie menstipe sal nie net uit die rasionalistiese kan lewe nie, maar sy hele wese moet in die essensiöle van sy lewensbestaan betrokke wees.

DIE OPVATIIINGS AANGAANDE DIE GODDELIKE

God bestaan in Afrika sonder dat daar bewysvoeringe is dat $\mathrm{Hy}$ wel bestaan - dit was nog nooit ernstig onder bespreking nie. Aanvaarding is die basiese verstandsaktiwiteit ook in hierdie verband, soos baie ander aangeleenthede bloot aanvaar word. Daar is nooit geargumenteer of God bestaan al dan nie - 'n aangeleentheid warmee die Westerse filosofie hulle vermoei het. Basies veronderstel die wese van bestaan die realiteit van die goddelike. Die vraag of God daar is, is nie 'n epistemologiese vraag nie. Net soos in die geval van die natuurwetenskaplike wie se -334- 
ondervinding bo die gegewens van sy laboratorium uitstyg omdat hyself 'n mens is, so ook is die primale mens se bewustheid van die goddelike nie bloot rasioneel gegrond nie maar word dit deur sy intuisie en as gevolg van sosiale samehang aanvaar. Natuurwetenskaplikes kan nie die ordelikheid van die wèreld bewys waarin hulle 'n geloof het nie; net so het die Swartman van Afrika geloof in goddelike teenwoordigheid en goddelike betrokkenheid.

Die eksistensiële reaksie teen die tipe objektiwiteit wat nie die vraag van persoonlike betrokkenheid vooropstel nie, is nie vreemd an die benadering in Afrika nie. Die verstandsboklemtoning in verband met 'n stel proposisies, die indruk wat die Sondagskool en katkisasieklas by die sendingstasie dikwels gee, vind nie navolging in die onafhanklike kerke nie. Deur deelname, deur betrokkenheid word die leer as 't ware "ingesien", deel van hom. Geloof in Afrika word hie in die eerste plek as 'n epistemologiese term, d.w.s. as fides, aangewend nie maar eerder as fiducia (vertroue), d.w.s. as 'n nie-epistemologiese aksie. Geloof is nie ' $n$ houding gegrond op stellings nie, maar dit is op verhoudings gegrond. Hier vloei die een ondervinding in die ander: die verhouding is sterk en die ondervinding is betekenisvol alleenfik omdat dit op persone of bonatuurlike magte betrekking het. Die linguistiese analiste het aangedui dat empiriese analise nie meer as kriterium vir die betekenis van iets geneem kan word nie - nie die betekenis van 'n bewering is belangrik nie maar sy eksistensiële gebruik. Nie dat die linguistiese analiste met hulfe antimetafisiese benadering in die konteks van die Afrikadenke iets te sè het nie, behalwe dat in Afrika religie, in dié geval ook teologie, utilisties en pragmaties eerder as metafisies en idealisties moet wees, ten spyte van die rol wat laasgenoemde wel speel.

In Afrika is dit die "vanselfsprekende" soort geloof wat aangetref word, eerder as dié wat deur logiese redenering bereik word. Dis ineer die dieper liggende sensitiewe aanvoeling as die serebrale aanvaarding wat predomineer, en hierdie benadering bly teenoor die hedendaagse obsessie wat daar heers oor die laaste woord wat die rasionele spreek. Dit is reeds hierbo aangedui dat daar baie maniere is om iets in die groot heelal te ken wat nie ten volle deur enige spesifieke tipe van benadering begryp kan word nie. Die hele mens is in warneming betrokke - die mens wat as 'n denkende, voelende en willende eenlseid funksioneer. Dit $-335-$ 
beklemtoon die inheemse Afrika-tipe van Christendom (en selfs Islam volgens ' $n$ ondersoek wat ons onder swart Moeslims alhier gedoen het). Diegene wat die serebrale aspek insake die verstaan van die Godheid en sy skepping beklemtoon, erken dat die benadering nog steeds met die onopgeloste misterie sit. Oortuigings is nie bewys nie maar eenvoudig erken en aanvaar.

Die tradisionele Swartman is skaars bewus daarvan dat hy sy omgewing interpreteer. Eintlik erf hy die interpretasie en eksperimenteer nie verder nie (ons kom later hierop terug). Wat hy gedoen het, is al vir hom besluit. Strak lewenspatrone is neergelè, en daarbinne het allerhande taboes, gebruike en rites hom gehou. Vryheid het hy nie leer verstaan nie, en die hedendaagse individualistiese begrip wat F.H. Bradley as "vry van" i.p.v. "vryheid tot" noem, het hom dikwels tot anargie gelei sover dit sy lewenspatrone betref. 'n Verwarde menstipe het dikwels in die stede ontwikkel.

Daar word dikwels gesê dat die Opperwese vir die tradisionele Swartman nader gekom het al hou hy nog aan sy tradisionele godsdiens vas. Wat wel gebeur het, is die volgende: God het formeel nader gekom; eksistensieel was Hy vir die Swartman altyd agter alles, maar dis weens sy grootheid moeilik om met Hom kontak te mak, net soos dit moeilik is om met die opperhoof kontak te makk, byvoorbeeld enige persoon, wie hy ook al mag wees, moes wag, selfs dae wag, voordat hy 'n oudiënsie met Dingaan kon kry. Verder, as God Homself geopenbaar het soos $\mathrm{Hy}$ is, sou die mens se outonomie in God se teenwoordigheid skade gely het. Die teenwoordigheid van God is meer as wat die mens kan dra. Hier lè die rede waarom die voorvadergeeste eerder genader word as die Opperwese. Dit is op een lyn met die tradisionele hiërargiese struktuur. God is dus nie willekeurig ' $n$ Deus Absconditus nie - God is dit formeel maar nie eksistensieel nie. Hy reflekteer Homself deur verskillende middelaars wat sy gawes aan die mens oordra, hetsy genesing, welsyn, voorspoed en so meer.

'n Belangrike aspek moet hier gemeld word. Daar word in die Swart teologie in Suid-Afrika baie klem gelè op menslikheid en menswaardigheid. Ook in verband met sy godsbegrip wil die Swartman die eiewarde van die mens vooropstel. God is daar, maar Hy oorheers nie die mens nie; 
Hy laat die spontane ontwikkeling van die mens toe. Vir hom gebruik die wèreld as middelaar 'n goddelike aktiwiteit wat basies goed is - God is agter die vee, die velde en laat dit groei tot voordeel van die mens. Deur die geestelike wesens en die "lewende dooies" word "n simbiotiese verband met die lewendes in hulle fisiese konteks gehandhaaf, en hulle op aarde weet dat agter dit alles die voortdurende goddelike handelinge is. Geen wonder nie dat alles wat die Swartman doen, in religieuse handelinge gekleur word.

\section{DIE STERK GEMEENSKAPSGEVOEL}

Op só veel maniere word dit beklemtoon. Die tradisionele mens van Afrika is deel van baie subjekte wat die wèreld uitmaak. Hy word nie deur dinge omring nie maar deur wesens; hy sien wesens in elke ding, nie objekte nie. Hy voel hom deel van alles rondom hom. Sy denke is eerder sinteties as analities georiënteerd. In hierdie sintetiese denke hang alles saam en het dit 'n religieuse waarde: die lewe word nie in verskillende kompartemente ingedeel nie. Alles word onder die religieuse sambreel gestel. Die tradisionele mentaliteit het nie plek vir iets wat religieus neutraal is nie. Al doen dit min analise, is die situasie, die geheel van die realiteit van oorwegende belang.

Dit alles gee 'n sterk totaliteitsoriëntasie, wat ook in die intense gemeenskapsgevoel gereflekteer word. Deelneming is in alle opsigte belangrik: daar word geen gevestigde lyne tussen die mens en die wêreld rondom hom getrek nie. Ook word die wèreld nie soos in die moderne natuurwetenskap geobjektiveer nie. Hy is deel daarvan en hy neem aan dat alle wesens soos hy daaraan deeineem.

In die moderne denke heers die beginsel van identiteit, naamlik dat $A$ nie tegelyk beide $A$ en $B$ kan wees nie. Verhoudings bestaan vir die moderne denke, maar daar is nie 'n deling van syn nie.

Vir die tradisionele Afrikaswartmens is 'n gemeenskaplike wesenseenheid heeltemal moontlik. Dat ek ek is en nie die ander nie, dat die ander ' $n$ ander is en nie ek nie, word nie aanvaar nie. 
Die persoonlikheid van die lewe voer die botoon in die Swartman se lewenshouding, en persoonlikheid veronderstel verhoudinge. 'n Sterk sin vir gemeenskap gebore uit bogenoemde opvattinge in verband met die omgewing en die medemens is die ooglopendste feit in Afrika. Die baie klein inheemse onafhanklike kerkgemeenskappe en religieuse bewegings is nie bloot aan tweedrag te wyte nie maar meestal om die intieme karakter van die gesin, die familie, die stabiele gemeenskap wat vroeër saamgewoon het, tot en in die dood te bewaar. Die mens in Afrika is familie, is gemeenskap. Al die handelinge van geboorte tot sterwe en daarna bind die persoon as gemeenskapswese aan almal rondom hom en veral ook aan dié wat gesterwe het en diè wat nog gebore sal word. Offerandes is simboliese maaltye wat op saamwees nadruk lé; so is die nagmaal en veral ook Paasfees vir baie van die onafhanklike kerke. Hulle wat sterwe, gaan in in 'n toestand van kollektiewe "onsterflikheid", en hulle bly tydgenote van die agtergeblewenes solank daar diegene is wat offers ter ere van hulle aanbied. Ontologiese harmonie is van primère belang.

Die sirkelhuise dwarsdeur Swart Afrika simboliseer ook die saamwees en gelykheid. Deur die eeue der eeue is nèrens in tradisionele Swart Afrika 'n ander vorm van huis voortgebring nie. Ook hierdie vorm is aanvaar en oorgedra. Hier sit hulle van aangesig tot aangesig in 'n sirkel rondom die vuur; so word daar in 'n sirkel gesit en gedans; ook in die onafhanklike kerke - dit benadruk die gelykheid en saamwees. Die opvatting van mens wees is ver meer dié van die Bybelse uitgangspunt as die individualisme van die moderne wèreld. John Taylor sê tereg: "Learn from Africa how to see Man as the Bible does" (Primal vision, p.117). Volgens die Bybel bestaan die mens nie vir homself nie, dit wil sè in en vir homself nie - hy bestaan nie in sy identiteit nie maar in sy betrokkenheid. So ook in Afrika.

Die ontologie van die Swartman in Afrika is basies antroposentries; die mens is in die sentrum van bestaan maar dan die mens nie as individu nie maar as gemeenskap, as familie, as die ander. Geseënd beteken om kinders en voedsel te hè en gesond te wees, mar dit is alleen die geval as die hele gemeenskap op hierdie wyse geseënd is. Dit is die rede waarom min van die onafhanklike Swart kerke en bewegings nie ook welsynsorganisasies is nie. Die mens vind sy ware self nie in isolasie nie. Om afgesny te word van jou groep is die groot vloek soos in die 
geval van Kain (vgl. Gen. 4:11 - 14; Ex. 12:17; 1 Kon. 9:7; 14:14 ens.). Seëninge is altyd gemeenskaplik (Gen. 12:23; Ps. 29:11; Gal. 6:16), as hieronder verstaan word die eie groep warin hy sy identiteit vind. In Swart Afrika is daar nog ' $n$ sterk sin vir die eie. Southall het in sy navorsing in Nairobi enkele jare gelede beweer dat hy nie een ontstamde Swarte in diè stad gevind het nie.

TYD IN DIE KONTEKS VAN SWART AFRIKA

Temporaliteit is so 'n fundamentele en ooglopende hoedanigheid in die menslike bestaan dat die begrip tyd onontbeerlik is vir ' $n$ bevredigende beskrywing of interpretasie van die wèreld en die mens. Dit is siklies vir primale volkere en lineèr vir die ontwikkelde volkere - vir sommige is dit sonder begin of einde.

Die postmoderne instrumente en denkbeelde het die mens se oë geopen vir die omvang van tyd maar ook vir die oneindige dieptes van lokale of nombliklike tyd. 'n Sekonde is nie meer 'n stukkie feitlik onbelangrike tyd nie - dit het groot betekenis gekry. 'n Elektroniese rekenaar bereik in een sekonde wat groot spanne van menslike rekenaars maande en selfs jare gekos het. Om van 'n miljoenste en selfs biljoenste van 'n sekonde te praat is vandag algemeen. Die postmoderne wetenskap het die diepte van tyd nog meer laat besef weens die uitgestrektheid van die sterrehemelruim. Na Charles Darwin se tyd kan die gedagte dat die wèreld bloot 'n masjien is en dat tyd verbygaan sonder om onverbiddelike veranderinge mee te bring, nie meer gehandhaaf word nie. Daar word basies natuurlik met hom verskil oor wesenlike aspekte van sy evolusieteorie, maar tyd het wel in dinamiese betekenis.

Tyd en ruimte is in die tradisionele Afrikadenke nou verbonde aan mekaar, ondat tyd deur inhoud gedefinieer word. Die plekke van die Bybel word geografies in die teenwoordige tyd geplaas, aangesien hierdie gebeurtenisse van die plekke in die teenwoordige tyd vir die welwese van die groep van belang is. So is die Swartman ook misties gebonde aan die plek waar hy gebore is. Daarom ondervind baie van hulle diep psigiese steuringe as hulle rondskuif of -geskuif word. Om die psigiese probleme te oorkom doen die onafhanklike kerke veel deur hulle intieme gemeenskapsvorming, godsdiensoefeninge met sang, handgeklap, dans, $-339-$ 
genesing en so meer - 'n geweldige katharsismiddel. Baie psigiatriese werk word in die bewegings gedoen.

Tyd bestaan in die tradisionele denke uit gebeurtenisse, d.w.s. wat gebeur, wat gebeur het of wat gou sal gebeur. Die toekoms is nie ' $n$ gebeurtenis nie en speel ' $n$ mindere rol in Afrikadenke, terwyl dit in die Weste 'n sentrale rol speel, sodat die Westerling skaars in die verlede lewe en baie min in die teenwoordige tyd, maar sy hele wese word op die toekoms gerig.

Die tradisionele Afrika-opvatting van tyd is basies tweedimensioneel met 'n dinamiese teenwoordige tyd en 'n lang verlede (vgl. J.S. Mbiti, Eschatology in an African background, OUP, 1971, P. 24). Die toekoms in die sikliese tydsopvatting word sterk gedevalueer. Net gebeurtenisse kom en gaan, en omdat die toekoms nie eksistensieel hierby ingeslote is nie, is dit van geen belang nie. Daar bestaan in Afrika ook geen mitologie oor die einde van die wêreld nie.

Die swaartekrag van tyd lè vir die tradisionele mens van Swart Afrika in die verlede. Tyd beweeg as 't ware agteruit en gaan van die teenwoordige na die verlede. Dis in die verlede dat die mens se wese sy oriëntasie vind: daar lè sy wortels. Dit is duidelik uit die mites, gesegdes, spreuke, rituele, gebruike, tradisies en so meer. Die toekoms is ' $n$ kort periode - in enige Swart taal in Afrika druk dit meestal niks meer as 'n paar maande uit nie.

Verder, die teenwoordige moet in die 'verlede' inpas - dit is dus duidelik waarom die Ou Testament so sterk die geografiese en geestelike basis van die inheemse onafhanklike kerke vorm. So pas die tradisionele teenwoordige in die Bybelse verlede in met sy heilige plekke, heilige tye, heilige persoonlikhede. Die klassieke tweedimensionele opvatting van tyd in Afrika en dat die teenwoordige in die verlede moet inpas, is verantwoordelik vir die statiese opvatting van die menslike bestaan. Die tradisionele Swartman vind sy wortels via die Ou Testament terug in baie van die onafhanklike kerke. Moses, sy Moses, word sy bevryder. Die verlede is die norm, eintlik die finale bestemming van alle dinge, die finaliteit van alle dinge, sodat die nuwe Jerusalem van 'n beweging die 
plek word waar die hemelse toestand herstel word en die eskatologie in 'n sekere sin gerealiseer word.

Die Swartman van Afrika kontroleer sy tyd; hy word nie daardeur gekontroleer nie. Tyd word deur die mens geskep, en die mens oefen daaroor beheer uit. Dis nie tyd wat van belang is nie maar die gebeurtenis - nie die betyds wees vir die kerkdiens nie maar die oomblikke van deel wees daarvan, al is dit by die uitspreek van die seën - dis van oorwegende belang. Tyd word gemeet aan die intensiteit van in gebeurtenis. Daarby is sekere tydsbestekke sakraler as ander, byvoorbeeld middernag, sonsopkoms en so meer. Vir offerandes het die "lewende" tyd spesifieke waarde, soos wanneer die oeste ingesamel word. In die onafhanklike kerke is daar plaasvervangers hiervoor - groot saamtrekke soos die Juliefees van die Shembebeweging. Paasfees is dit vir die Zion Christian Church op Morija. Hierdie tye is intens, want die gebeure is intens. Tyd is ' $n$ stroom van gebeurtenisse, en waar hierdie gebeurtenisse die kragtigste is, daar word tyd gemeet.

Die lewensiklus vanaf geboorte tot ingang in die voortgesette stamgemeenskap in die lewe hierna is nie 'n beweging die toekoms in nie maar is ' $n$ beweging in die trurat. In hierdie denke is daar gcen einde van die wereld of Messiaanse hoop nie. Daar is geen kulminasie van iets in die toekoms nie. Die eskatologiese konsepte is nie werklik eskatologies nie: die einde is in die verlede. Daar is ook geen nadruk op finale vervulling nie - vervulling kan reeds hier bereik word.

Met die koms van die Christelike sending, Westerse onderwys, natuurwetenskap en tegnologie, snelle sosiale verandering het chaos in die Swartman se bestaan begin intree. Hiervoor is die sending egter nie verantwoordelik nie, want die tweespalt tussen dio sekulère en die religieuse het die sending nie probeer skep nie. Dit was en is nog steeds 'n traumatiese ondervinding in Afrika dat godsdiens en die mens se daaglikse lewensbestaan geskei word. Dis een van die belangrike redes vir die ontstaan van die onafhanklike kerke. Verder het die tydsverskuiwing vanaf die verlede na die toekoms 'n gevaarlike onstabiele situasie in Afrika geskep; 'n disharmonie as gevolg van die vorming van wat L.S. Senghor "'half-caste' cultures" noem. Die verandering vanaf die tradisionele konsep van tyd tot die nadruk op die toekomsdimensie -341 - 
het tot sosiale en politieke onstabiliteit gelei. Die feit dat tyd 'n gebeurtenis is en dat daar vir die gebeurtenisse van die toekoms beplan moet word, het nog nie voldoende in Afrika deurgedring nie. Vir die toekoms moet gewerk word; daar moet vooraf georganiseer word. Die voordele van die toekoms val nie sommerso in ' $n$ mens se skoot soos manna in Moses se tyd nie.

Die Christelike teologie, wat as vanselfsprekend aanneem dat die lineère konsep van tyd die Bybelse benadering is, is geheet en al op die drie dimensies van tyd georiënteer. Die Nuwe Testament stel twee dimensies van tyd, naamlik die historiese teenwoordige tyd van die kerk en sy vervulling met die parousia. Christelike eskatologie sien alles beweeg na 'n toekomstige doel, waar alles volmaak sal wees, maar so dikwels is dit in Afrika op 'n piëtistiese wyse verkondig asof al die mooi dinge deur geloof sonder enige verband met werke sal gebeur en dit in -'n kontinent waar 'n werkfilosofie noodsaaklik is. Die boek Openbaring benadruk die "futuristiese eskatologie" baie sterk. Die terugkyk na die verlede het egter 'n vaste basis gelè vir die meeste onafhanklike kerke wat die geografiese Ou Testament daar ingebou het en verder dinamies laat word deur die prominente Nuwe-Testamentiese plekke daarin te laat leef. Die historiese alhier het by sommige 'n mitiese kleur gekry.

In die Nuwe Testament is die nadruk op die futuristiese element in die eskatologie. E. Schillebeeckx onder andere praat van "the biblical primacy of the future over the present and the past" en voeg by dat ons nie na die Bybel sal terugkyk nie - dikwels die probleem van die kerk veral ook in Afrika - maar vorentoe sal kyk met die Bybel en dat die teenwoordige en die verlede georiënteer sal wees na 'n nuwe realiteit wat nog sal kom (vgl. God the future of man, vert. N.D. Smith, Sheed and Ward Inc., 1968, p. 35, 36). Alles moet na God se toekoms georiënteer wees. Also ondervind en verstaan die mens die wêreld nie as 'n statiese sisteem waarin die toekoms nie deterministies van oorsaaklike faktore van die verlede alleen afhanklik is nie, maar as ' $n$ dinamiese proses met uiters nuwe moontlikhede en werklikhede. In hierdie konteks sal die mens besef dat die toekoms iets is om te verkry, nie net om te ervaar nie, en dat wat verkry word, deur die God van die toekoms geaktualiseer moet word. 
Die misterie van die toekoms is eksistensieel 'n basiese hoedanigheid. Die misterie van die oorspronge en bestaan in die verlede was en is nog altyd vir Afrika wonderlik en fassinerend - nie vir die gesekulariseerde wêreld nie, want dit is die misterie van wat reeds gebeur het. Wat nou die meeste saak mak, is die misterie van wat nog nie gebeur het nie en wat altyd nog in die aangesig gestaar moet word. Die tradisionele Afrikamens het sy tydsnadruk op die verlede geplaas; die gesekulariseerde mens plaas dit in so 'n mate op die toekoms asof hy alleen die toekoms skep. 'n Balans moet gevind word tussen die Afrikabeeld in hierdie opsig en die hedendaagse Westers georiënteerde beeld met sy obsessie oor die toekoms. Heelparty van die historiese kerke in Afrika is in hulle werklike taak meer op die verlede georiënteerd en in hulle geloof meer op 'n utopiese toekoms. Die mens het "mondig" geword in die sin van ongeëwenaarde kreatiewe en transformatiewe mag wat hy vir die bou van die toekomstige wèreld ontvang het. Hy is "onmondig" omdat hy nie weet hoe om dit alles te beheer sodat hyself en sy toekoms daarin verswelg word nie. Die mens kan homself in sy taak oorskat of onderskat. Daar is by die gesekulariseerde mens 'n oorskatting, of dit in Japan of die Weste is, en ' $n$ onderskatting in Afrika: hy het nog nie sy potensialiteite reg ingespan nie; eintlik weet hy nie hoe om dit te doen nie. Ons volgende groot sendingaksie in Afrika sal op die sekulère vlak lè, d.w.s. die mens voorberei om sy wéreld tot sy voordeel en tot eer van God aan te wend.

\title{
DIE VERANDERING WAT IN AFRIKA NODIG IS
}

\begin{abstract}
Afrika kan diepte gee aan die moderne wêreldbeeld met sy oppervlakkigheid waarteen die post-moderne natuurwetenskap reeds gereageer het. Maar Afrika het self in verandering in sy mentaliteit en algemene ervaring nodig. Die histories belangrike Copernikaanse revolusie, wat aan die moderne wetenskap geboorte gegee het, is gekenmerk deur 'n radikale verandering in die mens se mentaliteit en algemene ervaring. Die heersende intellektuele modus het ' $n$ merkwaardige omkering ondervind, 'n subtiele verandering in die mens se gevoele vir dinge en vir materie self - die bewustheid van ' $n$ nuwe samestelling van ervaring (Herbert Butterfield, The Origins of Modern Science, London, George Bell and Sons, 1949, P.104 e.v.).
\end{abstract}


Afrika se agterstand is te wyte aan die feit dat dit nie die aksiologiese era deurgemak het nie, d.w.s. nie in sy gedagtesisteem sekere konsepte ingekry het nie. Gedurende die periode van plus/minus 800 tot 200 v.C. is daar geboorte gegee aan veel wat die mens sedertdien op horisontale vlak kon wees; dit was een van die vrugbaarste tye in die vorming van die mensheid: hy word bewus van homself en sy beperkinge en stel radikale vrae aangaande die rede vir sy bestaan en sy toekoms. Gedurende dié tyd vind die aanvang van Indiese filosofie in die Oephanishads plaas; dis die tyd van die Griekse filosowe, van Siddharta Gautama, die Boeddha (563-483 v.C.), met sy diepsinnige vrae oor die mens en oor wat bestaan; Zarathustra van Persië (Iran), min of meer dieselfde tyd as Boeddha, met sy profetiese religie van keuse, beslissing en konflik; die Hebreeuse profete met hulle sobere benadering van die ontwikkeling en gebruik van die gawes van God in die natuur en hulle nadruk op reg en geregtigheid; Confucius (5de eeu v.C:) in Sjina, met sy etiese beginsels vir die beskaafde mens in die gemeenskap - meer as twee duisend jaar lank was sy invloed kragtig in Sjina. Dan is daar die Bhagavadgita in Indië, wat heel moontlik net buite hierdie groot periode ressorteer. In die vroeë Indiese boeke was min van 'n persoonlike toewyding aan ' $n$ God met wie die mens in 'n persoonlike verhouding kan wees. Die Gita bring die aspek van Bhakti, 'n persoonlike teïstiese god, na vore.

Dit is onmoontlik om te verduidelik waarom daar in so baie wérelddele byna gedurende dieselfde tyd so 'n groot uitbarsting van kreatiewe mag was. Daar was moontlik geen ander periode van kreatiwiteit groter in die menslike geskiedenis as hierdie nie. Die fundamentele kategorieë waarin ons vandag nog dink, is in die tyd gebore. Dis die tyd waarin modifikasie van die denke van die mensheid plaasgevind het. Wat bestaan, die syn, word merkbaar vir die mens as analitikus, en filosowe mak vir die eerste keer hulle verskyning (vgl. Karl Jaspers, The origin and goal of history. New Haven, Conn., Yale University Press, 1953, p. 1-3). Dit was groot veranderinge in die menslike gees en vir die transformasie van die menslike bewustheid. Dit het Afrika nie meegemaak nie maar binne-in die sirkel van deduktiewe denke gebly sonder 'n diepgaande intellektuele analise van sy omgewing. Ook wat die tydsaspek betref, het die genoemde era in die tyd 'n toekomstige dimensie beklemtoon; ' $n$ doel in die menslike bestaan wat na vore gerig is. 
Die bekende professor Es'kia Mphahtele beweer elders tereg dat selfs die Afrikaliteratuur in sy geskrewe vorm, nie 'n lang tradisie het nie. Hy sê Afrika deel nie die intellektuele refleksie wat van Westerse kultuur afgelei word nie. Hy sé hulle mag die uiterlikhede van die Westerse beskawing hè soos kleredrag, eetgewoontes, sport en onderwys en so meer, maar Afrika is "uiterlik" eintlik in die 19de eeu in die Europese geskiedenis ingetrek. Hy sè verder dat as hulle literatuur in Europese tale onderwerp word aan die kritiese norme inherent in die tale, is die kritiek onregverdig. Dit is die uitbreiding van kulturele imperialisme. Dit is nie dat Afrika ' $n$ kinderlike kontinent is en in die Westerse beskawing opgevoed en geassimileer moet word en daarom "kwalifiseer" nie. Afrikaliteratuur moet in die historiese konteks gelees word. Die literatuur het eers in die 19de eeu verskyn, hoofsaaklik Christelike prosa wat te Lovedale Press (1823) die eerste keer verskyn het. Thomas Mofolo se Sothoroman Chaka in 1910 voltooi, het eers in 1925 verskyn, omdat dit $n$ verleentheid was vir die Franse sendelinge te Morija (Lesotho). Chaka word opgehemel, wat vir ortodokse Christene onaanvaarbaar is. Sol Plaatjie, skrywer van Mhudi, het ook sendelinge en Blankeuitgewerskringe verontrus met sy swart held, 'n skepper van geskiedenis: so iets was ondenkbaar. Swartes was nie veronderstel om geskiedenis te skep nie. Plaatjie se roman is in 1917 voltooi en eers in 1930 gepubliseer. Die literatuur voor Wêreldoorlog 1 was hoofsaaklik in die inheemse taal en was intens didakties in die Christelike rigting: as hulle dit nie doen nie het die sendelinge toegesien dat dit nie gepubliseer word nie. Later kom daar 'n skrywersbewustheid van die heersende sosiale toestande. Die aandag was en is nog hierop en nie op 'n bydrae wat op ander gebiede gelewer kan word nie.

Skaars het Afrika aan die vrugte van hierdie moderne era geproe of ' $n$ nuwe aksiologiese era het 'n aanvang geneem. Met die oorname van die positivistiese natuurwetenskapsbeskouing is die syn warin die metafisiese op die agtergrond geskuiwe is, ernstig verskraal. In hierdie nuwe era vind ons die samestelling van natuurwetenskap en tegnologie, wat eers nou verbonde was maar nou in mekaar ingevleg is. Na die 18de eeu het die Westerse mens ' $n$ besliste sprong gemaak as gevolg van die tegnologiese revolusie. Die afstammeling van die gekoppelde wetenskap-tegnologie het met sy geweldige vernuftige uitvindinge en prosesse tegnologiese doeltreffendheid miljoene male vermeerder. Nie net 
sy omgewing nie maar die mens self word getransformeer. Die mens se intellektuele moontlikhede verbreed en verdiep teen 'n geweldige tempo. Probleme duisende en miljoene male moeiliker as enige wat voorheen behandel is, word aangedurf. In sekondes word begryp wat voorheen maande en jare in beslag geneem het. As dit, soos instink by die diere, op die kinders oorgedra kon word, sou supermense gekweek gewees het. Die teenswoordige geslag van mense in die Weste en die Ooste (veral Japan) het magiese magte geskep deur kubernetiese wetenskap-tegnologie wat ongeëwenaarde moontlikhede meebring. Daar is ' $n$ sprong wat by ' $n$ deel van die mensdom plaasvind, maar die sprong is nie net natuurwetenskaplik-tegnologies gegrond nie maar is 'n nuwe "spiritualisasie" in die natuurwetenskap. Dit gaan terug op die nie-rasionele en nie net op die rasionele nie. Dis holistieser in sy benadering, en daar is 'n nuwe orde van menslike ondervinding. In hierdie proses is dit ' $n$ klein persentasie wat die rigting aangee, maar wanneer dit op bevatlikheid hiervan aankom, het diegene wat deur hulle kultuur voorbereiding hiertoe ontvang het, 'n geweldige voorsprong.

Dat Afrika 'n bydrae tot die ontsettende ontwikkelinge op tegnologies-natuurwetenskaplike gebied kan lewer, lyk in hierdie stadium twyfelagtig; die agterstand, net soos in die ekonomiese, word daarenteen groter. Natuurlik is dit ook te wyte aan die geweldige agterstand in tersiêre onderwys. Afrika het op verre na nog nie die vooroorlogse ontwikkelings ingehaal nie, en vandag verdubbel kennis om die 7 tot 8 jaar (in die 16de en 17de eeu het dit ' $n$ honderd jaar geduur). Aan die einde van die eeu sal dit glo om die twee jaar wees. Waar Afrika sy bydrae gaan lewer, is op die menslike vlak, d.w.s. die post-moderne mens help weerhou van bloot 'n masjien te wees, dat menslikheid sal seëvier.

Tyd en fisiese afstande in kommunikasie is tot byna zero gereduseer, sodat daar nou op aarde in 'n groot mate 'n gelykvormigheid van menslike ondervinding tot stand kom. Die mensdom kan wesenlik deelneem aan en meer ten volle betrokke wees in wat andere ondervind selfs op groot afstande van mekaar. Met die inkrimping van die wêreld sal mensverhoudinge 'n groot faktor bly. Die hele wèreld het die probleem en taak van almal geword. Dit is die totale metamorfose in die geskiedenis. Al die kritiese probleme het wèreldprobleme geword. Daar $-346-$ 
is ook al meer die besef dat die mensdom deur ' $n$ gemeenskaplike bestemming beheers word. Dit kan wees dat Afrika gouer by die natuurwetenskaplik-tegnologiese voortsnellende prestasies aanpas, maar dit kan ook wees dat sy groot bydrae sal wees on die menslike lewe menslik te hou en nie to dehumaniseer nie - 'n proses wat met die toenemende sekularisme al ver gevorder het. Daar is al meer die besef dat ons alinal deur 'n gemeenskaplike bestemming beheers word.

AFRIKA EN DIE NATUUR

Afrika het nog nooit los van die natuur gelewe nie. Die post-moderne natuurwetenskap besef terdeë dat die mens nie los van die natuur kan bestaan nie. Die mens is 'n integrerende deel van die natuur, en die wèreld is 'n allesinsluitende gemeenskap - soos die aarde se materie en energie, sy grond en mineraalneerslae, sy atmosfeer en water, sy plante, diere en menslike wesens, sy persoonlike en sosiale werklikhede, sy baie verhoudings en gebeurtenisse - alles tesame is 'n sistemiese geheel eerder as bloot losse bymekaar gegocide selfgenoegsame onafhanklike entiteite. Afrika het nog nie hierdie geheelheidsuitgangspunt ontgroei nie. Gelukkig het die moderne wetenskap sy fisiese wêreldbeeld nog nie op Afrika kon afdruk nie. Byna alles wat deur die uitgangspunt van die materie gese is, word vandag verwerp. Die atoom het in sekere sin vir die fisikus 'n nisteriewèreld geword.

Die tradisionele wetenskaplike opvatting van substansie kan nie meer op die mikrowèreld van die atoom toegepas word nie. Misterie verwys hier na wat onkenbaar is, onbegrypbaar en selfs ontoeganklik vir die menslike verstand in sy volheid. Misterie velwys na die kwantiteit van die onbekende. Hierin toon die post-moderne natuurwetenskap 'n pragtige beskeidenheid - anders as die natuurwetenskap van die moderne era. Verder verwys dit na die "kwaliteit van die bekende". Daar word aangevoel dat dit meer inhou as waaroor ons voldoende kan praat of waartoe ons deur streng rasionele analise en beredenering kan deurdring. Dit het nie-rasionele elemente wat net deur intuïsie aangevoel kan word eerder as deur streng beredenering. Volgens hierdie standpunt verminder en verklein of elimineer die vermeerdering en verdieping van kennis nie die sin vir misterie nie maar intensiveer dit. In hierdie benadering het Afrika met sy sterk gevocl vir die religieuse iets by te $-347-$ 
dra. As die post-moderne natuurwetenskap na die natuur kyk as misterieus, hoe moet die teologie nie staan teenoor die almagtige Wese wat dit alles voortgebring het nie? Heel moontlik kan die inheemse kerke hulle bydrae lewer veral in 'n tyd van die vervlakking van die teologie en die homogenisering (Marcuse) van die menslike bestaan. Waarom word Afrika ' $n$ Pinksterkontinent? is dit deels ' $n$ reaksie teen die horisontalistiese teologie van die historiese kerke, wat, op die Roomse Kerk na, in getalle sterk afneem? As fisici van wèreldformaat soos Otto Hahn, Von Weisz\&da.cker, Heisenberg en andere na die godsdiens gedryf word weens die wonder agter die materie en die misterie daaragter, dan is dit nie vreend dat orals geleerdes godsdienstige bewegings lei of by sodaniges aansluit waar die rede nie alles oorheers nie maar ook die intuisie, "gevoel" (in Schleiermacher se sin van afhanklikheid van God) en ander nie-rasionele faktore ' $n$ rol wil laat speel. Daar is vandag nie so ' $n$ huiwering om aan die buitenatuurwetenskaplike dimensies van die natuur ' $n$ plek te gee nie. Die natuur het weer vir die natuurwetenskaplike menslike bewussyn 'n ope venster geword na die finale werklikheid wat die immanente en die transendente omspan. Dit wek ' $n$ misterie op wat verder as bewondering strek, dit lei tot aanbidding van die Skepper van dit alles. Dit is interessant dat daar weer ernstig en radikaal oor "God" gedink word - radikaal in die sin van na die basiese betekenis van dit alles te gaan. Daar is baie wat vandag verontrus is oor die voor die hand liggende feit dat die Westerse kultuur tragies uit pas is met die basiese karakter van die heelat. Daarby word die mens se dringende vooringenomendheid met materiële waardes afstootlik, terwyl die heelal fundamenteel nie materialisties is nie mar verhoudingsgeoriënteerd; hier is sensitiewe wisselverhoudinge basies. As dit die geval is - wat dit wel is -, dan is dit moreel verpligtend vir die mens om meer begaan te wees oor verhoudingswaardes - in aspek waarop Afrika in sy hele bestaan sterk klem lè. As die kwaliteit van hierdie heelal, van die individu en van die gemeenskaplike lewe so afhanklik is van geheelheid en allesomvattende dryfvere, dan is bewuste samewerking en individualiteit in gemeenskap van die hoogste waardes in die mens se bestaan - eerder as skeiding, totale onafhanklikheid, vlymskerpe kompetisie en individualiteit ter wille van individualiteit. 
DIE INHEEMSE KERKE IN DIE NUWE AFRIKA

Daar is verskillende faktore verantwoordelik vir die opbou van Afrika: die verskil tussen die arm en ryk lande is in 'kreatiewe' modernisering geleë. Waar daar beplan en gewerk word, daar is vooruitgang - waarvan Calvyn in sy Genève ' $n$ voorbeeld was. Hieroor het R.H. Tawney en Max Weber genoeg te sé gehad. Sosiale transformasie vind plaas waar die mens sy menslike potensialiteite sistematies ontwikkel; waar die waarde van die toekomsdimensie begryp word en vir die gebeurtenisse wat daarin moet plaasvind, beplan word. Moderniteit het 'n wèreldbeeld gekonstrueer waarin daar 'n groot element van sosiale, ekonomiese, politieke en tegniese verandering betrokke is. Dit het die mens sogenaamd mondig gemaak van die bonatuurlike magte waarvan hy geglo het dat hulle sy lewe beheers. Dit lyk asof ontwikkeling in Afrika nie vorder nie; inteendeel, lande wat relatief voor onafhanklikheid goed daaraan toe was, het ernstige ekonomiese en ook selfs politieke terugslae ondervind. Die Wèreldbank voorspel dat teen 1990 oor die sewentig persent van Swart Afrika se bevolking in wat hulle as "absolute poverty" beskryf, sal lewe. Nou is die vraag of die klem nie op ontwikkeling meer as enigiets anders moet val nie. In diè verband kom ook die feit na vore dat Marxisme moeilik vat kry war industrialisasie nie 'n vastrapplek gekry het nie.

Godsdienste het dikwels 'n remmende invloed op ontwikkeling weens hulle konservatisme, hulle verstardheid. Dit word ook bevraagteken of die wèreldbeeld wat in 'n religieuse sisteem gevind word, in staat is om die gedagtes oor die natuur, tyd en geskiedenis, die mens en die gemeenskap te kan ondersteun, wat integrerende dele van moderne ontwikkeling is

Swart Afrika word vinnig die tweede grootste kultureel-geografiese gebied in die hele geskiedenis van die uitbreiding van die Christendom en hoofsaaklik as gevolg van die selfbeweging van die kerk. Dieselfde geloof wat die Europese ontwikkeling gelei en koers gegee het, het Afrika ontvang - 'n wêreldbeeld wat kan behou en skep; en dit is belangrik vir ontwikkeling. En tog lyk dit asof dit onseker is of die godsdiens in Afrika die ontwikkeling kan help handhaaf en uitbou. As hulle dit nie meer kan doen nie en totalitëre state ontwikkel, na wie toe sal hulle gaan?

Op hierdie kontinent is daar 'n groot beweging aan die gang, met nuwe godsdienste en onafhanklike kerke, sogenaamde kultusse en sektes. -349 . 
Presies honderd jaar gelede het Nehemia Tile sy kerk in die Transkei gestig as gevolg van die aanstelling van magistrate van die Kaapse regering. In Suid-Afrika het die onafhanklike kerke toegeneem van 800 in 1948, wat 9\% van die Swart bevolking uitgemaak het, tot 3270 in 1984, met 6 miljoen van die Swart bevolking van Suid-Afrika wat daaraan behoort. Die Zion Christian Church se Paasfeesbyeenkoms by Morija is deur tussen driekwart miljoen en een miljoen mense bygewoon. Al lyk dit of hulle niks te doen het met betrekking tot ontwikkeling nie, wil ons kortliks aantoon wat wel aan die gang is.

In die primale religieë van Afrika se tradisionole mitologie van verwagtinge leef die gedagte van 'n terugkeer na 'n paradysverlede eerder as ' $n$ vooruitbeweeg na 'n nuwe bestaansorde waar nooit voorheen aan gedink is nie. Die onafhanklike kerke, buite die historiese kerke, dien as ' $n$ vorm van aanpassing by ' $n$ buitengewoon strawwe en uitgerekte traumatiese ondervinding warvan daar geen ontvlugting is nie. Die sekularisasieproses vreet soos 'n suur alles wat geestelik is, op, en hierteen reageer Afrika op sy eie wyse. Hierdie onafhanklike religieuse bewegings het universele potensialiteite en lewer hulle bydrae tot die aanpassing van tradisionele mense by meer ontwikkelde gemeenskappe. Hier is nuwe religievorme wat hoogs belangrik is vir die moderne proses.

Wat is hier aan die gang? Die algemene reaksie is om die bewegings af te maak as onbelangrik of as reaksionêre hindernisse in werklike ontwikkeling soos dit die geval was met die tradisionele of primale gemeenskappe waar hulle van afstam. Die nuwe religieë en onafhanklike bewegings word gesien as die verandering van 'n mikrokosmiese na 'n makrokosmiese beskouing. Van Binsbergen, wat religieuse veranderinge in Wes-Zambië in resente tye beskrywe, skryf dit toe aan die tydsbegrip, houding teenoor die natuur, konsepte betreffende die gemeenskap en die verklaring van wat boos en sleg is, in terme van die gemeenskap en nie soseer in terme van persoonlike moraliteit nie (vgl. W.M.J. van Binsbergen, Religious change in Zambia: Exploratory Studies, London/Boston, Kegan Paul, 1981). Van Binsbergen is nie soseer geïnteresseerd in religieuse voorstellings en denkbeelde as sodanig nie maar in hulle verhouding tot aspekte van die sosiale struktuur. Waar mikrokosmiese grense afgebreek word en die mense by 'n wyer wèreld aanpas, daar lei dit tot veranderde sosiale strukturele toestande deur -350 - 
meer universalistiese religieuse denkbeelde na vore te bring. Nie-religieuse faktore het ' $n$ invloed op religieuse aspekte. Van Binsbergen beweer verder dat die nuwe maniere van produksie die beginsel is agter sommige van die belangrike veranderinge in die Zambiese religie. Religie alhier is ' $n$ integrerende, infrastrukturele deel van die gemeenskap, wat, volgens hom, nie van kapitalisme gesè kan word nie. Marxisties geïnspireerde konsepte soos wyse van produksie, klassekonflik en vervreemding word gebruik. Die verskillende wyse van produksie bring spesifieke denkbeelde in omloop wat die integriteit van die plaaslike landelike gemeenskap raak. Dorpsbewoners word in sommige dele tot die boerestand en proletariërs gereduseer, en die nuwe religieuse vorme is pogings om die proses van klasvorming teen te staan deur die proses van proletarisering teen te gaan. Religieuse innovasie word met politieke en ekonomiese verandering geassosieer. Vir Van Binsbergen is daar ' $n$ dialektiese verband tussen religieuse innovasie en artikulasie, d.w.s. wyse van produksie, en religieuse innovasie is vir hom die negasie vaı die werklikheid van artikulasie. Nuwe wyse van produksie en die gepaardgaande religieuse veranderinge lei essensieel nuwe ekonomiese, sosiale en religieuse vorme in ten spyte van die uiterlike skyn van kontinuïteit. Vir hom is die Marxistiese model die toepaslikste vir die verklaring van verandering en die rol wat dit speel. Die wyse van produksie eerder as die etniese groep moet bestudeer word. Dit is wel so dat nie-religieuse faktore 'n rol speel, maar om alles afhanklik te stel van die prosesse van materiële produksie en die verandering daarin gaan nie op nie.

Van Binsbergen het nie ' $n$ besef van die baie invloede wat verandering meebring nie. Daar is dieper aspekte wat in aanmerking geneem moet word. Nehemiah Tile, die vader van die onafhanklike kerkbeweging onder Swartes, het al van "gemeenskaplike swartheid" en "swart bewustheid" gepraat. Om die bewegings toe te skryf aan die feit dat die Swartman nie die denkbeelde van die "primitiewe" kommunale gemeenskap ontgroei het nie, dat hy hom geen oplossing behalwe as magies-religieuse kan voorstel nie en dat later eers 'n meer realistiese lyn van 'n klassestryd gevolg word, is nie aanvaarbaar nie.

Die implikasie is dat hierdie bewegings argaïes, eintlik kontra-revolusionēr is en dat hulle die aanvaarding van politieke en 
ekonomiese aksie wat werklike ontwikkeling teweegbring, teenstaan. Dit is wel waar dat daar bewegings was en nog is wat ' $n$ soort paradyssituasie uit die hemel verwag - 'n ingesteldheid wat nie vreemd is aan die politieke utopie wat aan baie dele van Afrika eie geword het nie. Laat 'n mens begin by die Nonquase-insident in 1857 met die vernietiging van vee, graan, voedsel op die lande deur die Xhosas - hulle ekonomiese bronne. Hlier is ' $n$ nie-Christelike beweging met ' $n$ toekomsverwagting wat ' $n$ paradystoestand op aarde insluit, bewerkstellig deur ' $n$ soort magiese handeling, naamlik die vernietiging van hulle lewensbestaan, on die ondergang van die Blankes te bewerkstellig. Dle belangrike opperhoofsposisie is deur Blanke-indringing aangetas, en dit het die wéreldbecld van die Xhosas bectreig laat voel en hy reageer op irrasionele wyse. Dan is daar die geval van Alice Lenshina se Lumpakerk, wat met Kenneth Kaunda in botsing kom, omdat hulle polities bedreig gevoel het. Hier kom ook die geval Enoch Mgijima in 'n mens se gedagte. Sy volgelinge, "Israeliete", wat hulle onwettig op kroongrond gevestig liet, het Jan Smuts se troepe met kieries en skerp instrumente aangedurf nadat hulle hulle nie self van kroongrond wou verwyder nie. Hulle geloof was dat die koeëls van Smuts se soldate in water sal verander. Vir taglig was die koeëls die middag nie water nie.

Hierdie botsings was fel ondat vir die mense, wat hulle identiteit op hulle eie gebied wou behou, so veel op die spel was. Wat die onafhanklike kerk betref - baie gevalle van botsings tussen die nuwe profete en die regerings in Afrika kan aangelıaal word, soos onder andere die van Joseph Chilembwe, wat in 1915 in Niassaland (Malawi) die eerste onafhanklike kerk daar gestig het. Simon Kimbangu van die destydse Belgiese Kongo (Zaire) is kort na sy bewegings begin het, in die tronk gestop, waar hy na 35 jaar sterwe. In sy afwesigheid het sy kerk aangesterk tot twee miljoen, en vandag is dit vier miljoen, die grootste Protestantse kerk in Afrika.

Hierdie bewegings soek nie alleen na 'n eie Afrikaliturgie nie maal ook 'n eie kyk na die Skrif en hulle antwoord op hulle inheemse vrae. Hulle soek na 'n eie konfessie en wil hulle eie identiteit behou sowel as die intieme gemeenskap onderling; vandaar die feit dat hulle so in kleiner groepe verdeel hoofsaaklik vir die intensivering van die gevoel van "ons behoort aan mokaar". In hierdie bewegings is daar 'n sin vir arbeid en 
hulle is op ontwikkeling ingestel sonder on die geestelike te verwaarloos. Eintlik het hierdie kontinent 'n dramatiese behoefte aan ontwikkeling. Baie van die bewegings het ontwikkelingsprogramme. Verder word taboes ten opsigte van bruikbare voedsel, soos byvoorbeeld sekere diere, opgehef, fetisjisme met sy irrasionele kontrole oor menselewens word vernietig, alkohol en tabak word vermy, mense wat psigiese probleme het, word met groot welslae op hulle eie manier behandel. Waar twee kulture bymekaar kom soos in Suid-Afrika, sal daar beslis versteurılige wees, en alhoewel hier sielsieke-inrigtings vir Swartes is, is hier glo net een geregistreerde Swart psigiater - baie van die werk word by hierdie bewegings gedoen.

DIE REMMENDE FAKTORE IN DIE TRADISIONELE WERELDBEELD EN HOE DIE BEWEGINGS DIT BENADER

Daar is verskillende faktore wat die aanvaarding van 'n nuwe wèreldbeeld aanwakker sonder dat die religieuse inslag skade ly. Die nadruk op die doeltreffendheid van magie is onversoenbaar met 'n realistiese ekonomiese aksie vir ontwikkeling. Magie en 'n gesakraliseerde opvatting van die natuur gaan hand aan hand. Deur hierdie twee fasette word die natuurlike wereld feitlik vergoddelik of vergeestelik as die plek waar geeste woon en magte wat mag oor beide mens en natuur uitoefen. Agter alles word ' $n$ mistieke mag gesien wat in sekere persone en objekte sterk na vore tree. Alles word deur ritueel en taboes gekontroleer. Die mens voel hom ondergeskik aan die genade van die natuur. Hier het die mens se handewerk mar min invloed. Die invloed kom van die geeste. Wat ook al - siekte, natuurrampe, epidemies, hongersnood - alle negatiewe dinge kom van die geestewèreld en magiese handelinge. Die natuur kon nie beheer word nie; die mens word in die natuur beheer, wat self ook beheer word. Daarom word die natuur in sy chaotiese en onontwikkelde toestand gelaat en word dit nie beskou as 'n gawe wat gekontroleer, ontwikkel en geniet moet word nie ( $v g l$. $P$. Gheddo, Why is the third world poor? N.Y., Maryknol Orbis Books, 1973).

Die gedesakraliseerde beeld van die natuur met sy moontlikheid vir natuurwetenskap en tegnologie het sy vernaamste historiese oorsprong in Israel. As gevolg van die Bybel en die sekularisasieproses verstaan die Afrikamens die gedesakraliseerde wèreldbeeld. Eers was dit die $-353-$ 
geeste wat die wèreld bewoon en alle natuurkragte kontroleer het en wat hulle met duur offerandes moes tevrede stel. Vandag het die geeste nie meer die sentrale posisie in baie se lewe nie. Israel se geskiedenis openbaar 'n gedurige stryd teen magie, towery en okkultisme aan die een kant en aan die ander die vertrowe op geloof in een almagtige God, wat met gebed en gehoorsaamheid benader word. Daar is tans dieselfde stryd in die kerke en in die besonder in die onafhanklike kerke. Dikwels word fetisje verbrand, steun op magie verminder. Dit alles verwyder verstandelike inhibisies wat handelinge beperk, veral nuwe vorme van handelinge en vooruitgang warteen as gevolg van jaloesie langs magiese en okkultiese weg op 'n kwaadaardige wyse gereageer word. Nietzsche het die mens van sy tyd aangespoor tot 'n vreeslose benadering warin hy eksperimenteer sonder bande wat hom bind. Hy wou dit sonder die godsdiens, maar die Afrikaners van vandag wil dit met godsdiens doen. Nou dat die Swartman beter geestelike bronne het, kan hy verder beweeg.

Een van die gepaardgaande elemente in die nuwe wèreldbeeld is die ontwikkeling van 'n verantwoordelikheidsin by die individu vir sy eie welvaart en lot. Hierdie proses van "individualisasie" en die ontwikkeling van 'n verantwoordelikheidsbesef bevry die Afrikamens van die ou fatalismes en die ou vrese en vervang die negatiewe faktore in dic tradisionele strukture.

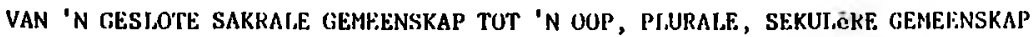

In die meeste tradisionele gemeenskappe word die stam, sy regeerders en instellings in ' $n$ heilige kosıniese orde geplaas wat deel vorm van die tradisionele wèreldbeeld. Die patrone en sanksies vir sosiale organisasie wat gewoonlik van hierdie kosmologie afgelei is, en sy verwante mitologie en die leiers van die geineenskap was belangrike kanale waardeur kosmiese geestelike magte vir sy welvaart opgetree het. Daar was nooit juis 'n skerp skeiding tussen religieuse en politieke instellings on aktiwiteite nie - die eienskappe van in unitêre en sakrale gemeenskap. Geen wonder dat die vroegste vorme van onafhanklike kerke en nasionalistiese politieke bewegings nou vertonde was nie. Eintlik het laasgenoemde bewegings hulle in religieuse vorme gehul wat die Bybel, liedere, kategismusse en 
so meer gebruik. Dit vind 'n mens ook by Marcus Garvey, die Jamaikaan, wat die Swartes buite Afrika na Afrika wou terugbring.

Gelukkig het Kwame Nkrumah se politieke koninkryk nie tot 'n nasionale godsdiens gelei nie, anders sou Afrika heelwat hiermee te doen gehad het. Die religieuse en politieke manifestasies van onafhanklikheid het in eie kring voortbeweeg. Die eerste het ontwikkel tot wat nou as die nuwe onafhanklike religieuse bewegings bekend staan, en laasgenoemde het die vorn aangeneem van Westerse tipe arbeidsunies, politieke partye en onafhanklike nasionale regerings.

Die onafhanklike bewegings in Swart Afrika het nie tot nuwe nasionale of staatsgodsdienste gelei nie. Hierteenoor het die nuwe politieke magte in Afrika die neiging tot 'n terugkeer na die tradisionele sakrale posisie met 'n unitère solidère eenheidsgemeenskap gegrond op die ou outokratiese model waarvan die hoof hom soms 'n pseudomessiaanse status toe-eien of deur sy volgelinge as sodanig verklaar word. Die meeste van die kerke en die onafhanklike bewegings handhaaf die onderskeidingsposisie tussen staat en kerk, en daar het al ernstige verskille tussen die twee op die kontinent ontstaan, en dit kan nog intensiewer word.

Die bydrae wat die onafhanklike kerke in Swart Afrika maak, is dat in iets meer as een geslag 'n geslote, sakrale en unitère gemeenskup omgeskep word in "n "moderne" sekulère staat en godsdienstig plurale gemeenskap waarin hulle aan verskillende kerke en godsdienste in plaas van net die tradisionele mag behoort. Europa het nog wat die verskillende godsdienste betref, na honderde jare 'n probleem van kontak met die verskillende godsdienste. Hierdie proses het egter die opperhoofskap ondermyn, veral die tradisionele mistiek om die opperhoof. Die ontwikkeling is verantwoordelik vir baie van die onstabiliteit op hierdie kontinent. Hierdie bewegings resakraliseer veel van hulle lidmate in die konteks van die nuwe gemeenskap met sy eie Bybelse mitologie, opdrag en sanksies. Die ses miljoen Swartes wat aan die 3270 onafhanklike kerke in Suid-Afrika behoort, is so sterk in hulle eie gemeenskappe ingenestel dat hulle nie vatbaar is vir 'n geslotn, sakrale, unitêre politieke gemeenskap wat alles in hierdie nuwe eenheid saamgooi nie. Suid-Afrika met sy industrialisasie en verstedeliking het 'n vlaag 
van die bewegings voortgebring - namate Swart Afrika dieselfde pad gaan volg, na dié mate gaan die bewegings hier toeneem. Hulle is oop mar nie op die wyse dat godsdiens in die agtergrond is nie. Dis juis die faktor wat hulle bymekaar hou. Die nuwe gemeenskap is in heeltemal nuwe sosiale struktuur, wat nie op die ouderdoins- of okkupasiegroeperings van die ou gemeenskappe gegrond is nie maar die vrye individuele keuse van sy lede. Op baie gebiede bied hulle groot moontlikhede vir leierskap. Dit is 'n radikaal ander tipe van sosiale vorm en also deel van die transformasie van die oue na die nuwe, beide in gemeenskap en in wéreldsiening. Ses miljoen Swartes in Suid-Afrika en hulle groei steeds - beweeg na 'n nuwe sosiale gemeenskap met 'n diep religieuse inslag, terwyl die historiese kerke, wat baie met die politiek te doen het, lidmate verloor na die bewegings toe.

\section{'N NUWE WERKSFILOSOFIE}

Motivering en doelstellings of mikpunte is bepalende faktore betreffende werk sowel as die sosiale strukture waarin met welslae gewerk kan word. Daar word al meer besef dat die essensiële voorwaarde vir ontwikkeling harde werk is. Nyerere het in sy Arushadeklarasie onder andere gese dat die energie wat in klets ("chattering"), dans en drink vermors word, 'n groot skat is wat baie tot die land se ontwikkeling kan bydra.

Die onafhanklike groepe in Swart Afrika het die lede tot in beter lewenstandaard gehelp weens morele hervorming, gesondheidsverbetering, minder geldverspillende praktyke en vaste gewoontes wat opgebou word om 'n sewedaagse weekprogram van hulle nuwe gemeenskap waarin die liturgie nie in die kerk agterbly nie maar ook in hulle werksituasie ingedra word. Hulle stel hulle geloof op die werking en seën van God. Hier word hulle aangemoedig, dit skep vertroue, inisiatief en uithouvermnë en aanpasbaarheid by die veranderende moderne situasie sonder om hulle integriteit te verloor, en die vryheid wat hulle het, gaan nie in politieke hallusinasies of histerie op nie. Nuwe intrekkers word in die stadsatmosfeer tuisgemaak en rigting gegee.

Waar moderne ontwikkelingswerkpraktyke en tradisionele Afrikapraktyke by mekaar uitkom, is dit die opvallendste waar Blankes as werkgewers 'n groot rol speel soos in Suid-Afrika en soos dit in ander dele was, onder -356 - 
andere in Kenya, Zimbabwe en so meer. Dit is interessant dat in die lande baie werknemers voorkeur gee aan mense wat aan die onaflanklike kerke behoort. Ek hoef nie hiervan voorbeelde te noem nie. Dit word orals opgemerk waar hierdie bewegings is. Selfs hulle wat krities staan teenoor die Sioniste as religieuse beweging, erken hulle waarde as werkers. Dit is nie dat hulle weens hulle beskeie optrede uitgesluit word nie, want hulle het op ander gebiede as arbeid ook 'n voorbeeldige lewenspatroon. Geen wonder dat daar by baie van hulle 'n opwartse mobiliteit is nie.

Hulle handhaaf ook 'n tipe van Stoïsynse etiek. Die streng Calvinistiese arbeids- en besparingsetiek is deur R.H. Tawney en Max Weber beskrywe. Die nuwe etiek onder die onafhanklike kerk met asketiese inslag vermy ook die luukse en lè klem op in eenvoudige lewenstyl. Hierdie etiek is nie in tradisionele Afrika te vind nie. In die Ooste word die askeet, die heilige mens, die hermiet as die hoogste ideaal gestel in die Hindoeisme is die sauyass $i$ die ideaal, die man wat die wêreld vaarwel sè en die asketıese weg volg soos in die geval van Gandhi. In Swart Afrika daarenteë is die beeld die van die "groot man", die man van mag (wat met die leeu, die olifant, die luiperd vergelyk word), van vitaliteit, rykdom, welvaart, sukses. Die Zoeloe Umkhos 1 Onkhulu, die jaarlikse eerste vrugtefees, was 'n geleentheid om hierdie koning magies te versterk. Tradisioneel is sy grootheid aan sy hoeveelheid vroue, vee en oeste gemeet. Vandag is dit sy (swart) luuksemotors, sy luuksehuis en lewenstyl - 'n lewenstyl met 'n opvallende konsumpsiemodel, want dit is ook hoe die hedendaagse lewenstyl gesien word. Dieselfde model is ook merkbaar in sommige van die ouer kerke en onafhanklike bewegings. Galilee Shembe, die stigter van die iBandla lamaNaznretha, het oor die honderd vrowens gehad en heelwat besittings. Bronne word vir bykomstige dinge verteer terwyl dit broodnodig is vir ontwikkeling. Afrika het deur die eeue 'n konsumpsiesindroom gehad in plaas van kreatief met beplanning bronne te ontwikkel.

Ten spyte van die Zion Christian Church se konsumpsiedisposisie onder die leiers sover dit luuksemotors betref, is hulle lewenstyl skaflik. By baie van die onafhanklike kerke vind ons ' $n$ radikaal eenvoudige lewenstyl. Terwyl daar aanvanklik by 'n aantal van die onafhanklike kerke die "groot heer"-beeld was, is daar by hulle vandag meer -357 - 
eenvoudigheid van lewenstyl, kleding en behuising. Josef Diagienda, hoof van die groot Kimbangukerk in Zaïre met oor die 4 miljoen aanhangers, handhaaf 'n heel eenvoudige lewenstyl. Die vise-prinsipaal van die groot Universiteit van lbadan in Nigerië lei kaalvoet en met 'n gebedskleed in Bybelklas voor die hoofdiens in sy kerk en dit in Yorubaland waar die konsumpsiesindroon en skreiende korrupsie duidelik in die oog skiet.

Orals het die lidmate van die onafhanklike kerke eenvoudige gebedsuniforms - skoon en netjies - met serpe en eenvoudige, selfgemaakte gemeenskapskostuums. Die meeste het geen kerkgeboue nie en vergader in wind en weer - 'n boom of 'n oop plekkie langs die pad of ' $n$ meent is al wat hulle het. Byna almal verbied die gebruik van tabak en alkohol. Die lewenstyl is anders as die van die hoogste laag in noderne Afrika. Laasgenoemde is gevorm deur die industrialisasieproses, deur die Westers ingevoerde tegniek en vermaak, deur die tabakfabriek en moderne brouerye. Brouerye is die grootste bron van staatsinkomste in baie lande in Afrika. Ook by ons is die inkomste van biersale hoog. Die regering van Kameroen spog daarmee in sy toeristeliteratuur dat brouery die grootste nywerheid is; die toeris is verseker dat hy drank orals in die land kan bekom al is ander goedere moeilik bekombaar. Hierdie nywerhede is kapitaal- in plaas van arbeidsintensief, gebruik gevorderde eerder as intermedière tegnologie en produseer niks behalwe gebruiksgoedere nie. Dit alles dra grootliks by tot die vermeerdering van die land se sosiale en gesondheidsprobleme eerder as om dit op te los. Hierdie vorm van industrialisasie is ekonomiese abnormaliteit en ook noreel onverdedigbaar in 'n ontwikkelende land.

As die ses miljoen onafhanklike kerkaanhangers in Suid-Afrika nie daar was nie, sou die toestand van die Swartes groter kommer gewek het. By die onafhanklike kerke in die algemeen is daar 'n gesonder sosiale en morele instink. Hulle etiese inslag is dikwels anders as dié van die kerke waarvandaan hulle afstam. Langs hierdie weg lewer die mense 'n bydrae tot die sosiale en ekonomiese ontwikkeling van Afrika. Die nuwe wèreldbeeld, arbeidsetiek en eenvoudige lewenstvl lei tot tasbare ekonomiese resultate. Orals in Afrika het van hierdie bewegings hulle eie ekonomiese aktiwiteite en geslaagde ekonomiese ondernemings wat nuwe 
idees en tegnieke bekend stel. Mense leer ook deur hulle die moeilike kuns om geld te hanteer.

Daar is faktore in hierdie bewegings wat ontwikkeling kan rem, soos byvoorbeeld die klem op die vir hulle ex opere operato-werking van die brood en die heilige water wat by nagmaal gebruik word. Ook is daar die totale verwerping van Westerse medisyne in baie van die kerke, wat ernstig klem lè op genesing deur heilige water, handoplegging, uitstamp van bose geeste uit die pasiënt en so meer. Die feit dat hulle in genesing klem lè op geloof, is belangrik, maar die toepassing is skeef. Daar is meer siekte in Afrika as ooit tevore. Die profeet-genees-tipe van beweging gee baie aandag aan geloofsgenesing - geloof, gebed, vas en sakramentele gebruik van "heilige" water en olie en die ondersteuning van 'n geloofsgemeenskap. Te veel word soms aan die "krag van die Gees" oorgelaat. Andere is weer a-polities en onthou hulle van enige kontak met die politieke lewe. Die meer millenialistiese bewegings is ontrlugtend van aard. Al is die beeld wat hulle gee, dié van ongeletterdes en halfgeletterdes en stadsplakkers, in vergelyking met die uitgebreide aktiwiteite van die onderwysprogram van die sendinggenootskappe en ouer kerke, het hulle veel te doen met ontwikkeling. Die ouer onafhanklikes het op Pinksterkerkgrondslag die werking van die Gees beklemtoon en onderwys vir hulle leiers vermy. Vandag word in 'n aantal bewegings goed opgeleide leiers gevind.

Die gevestigde kerke in Afrika is natuurlik ook aktief. Daar is egter baie faktore wat remmend op hulle ingewerk het. Die dosente in hulle teologiese seminariums was feitlik almal uit die Weste, 'n groot aantal waarvan niks van die inheemswording van die kerk begryp het nio. Dít het die onafhanklike kerke en kerklike bewegings al sedert die laaste eeu begryp. Die Afrika van die toekoms sal alleen kreatief wees en kan ontwikkel as hy homself herontdek en van hieruit die nuwe ontwikkelings in die wèreld onder die knie probeer kry en dit self kreatief in sy eie lewensverbande en omstandighede verwerk. 